\title{
THE POLITICAL THOUGHT OF THE BOOK OF REVELATION
}

\section{By Oliver O'Donovan}

Something rather curious occurs in the final chapter of John Howard Yoder's deservedly celebrated book The Politics of Jesus. The chapter is entitled 'The War of the Lamb'; and in it the author, having dealt extensively in the rest of the book with the foundations for Christian political thought in the Gospels and Paul, proposes to 'characterise briefly' the political stance of the Book of Revelation in the course of drawing some conclusions for the whole. The characterisation is indeed brief. It occupies one and a half out of the eighteen pages of the chapter, and attends solely to the image of the slain Lamb in chapter 5. Then, on the concluding page (having found space in the meantime for a four-page exposition of Phil. 2:6) the author returns to Revelation once more, to deplore, with some indignation, what he calls 'the beginning assumption of the irrelevance of apocalyptic, which has so often made it hard to see social meaning in the book of the Apocalypse, even though its entire message has to do with kingdoms and empires'. And finally, like the reluctant schoolboy athlete who breaks into a trot a few yards from the finishing-line, Yoder concludes his book with a rousing Latin quotation: Vicit agnus noster, eum sequamur. ${ }^{1}$

We may well sympathise with Yoder's ambivalence. On the one hand it appears that the Book of Revelation must be important for Christian political thought; on the other, the universal prejudice of church and scholarship is against it. The close scholarly attention paid to the general field of apocalyptic during the last quartercentury has elevated a long-standing instinct of caution into an academic orthodoxy. Apocalyptic, we are told, is

1. John H. Yoder, The Politics of Jesus (Grand Rapids: Eerdmans, 1972) 250. As though sensing the ambivalence in the author's mind, an editor at Eerdmans, with conscious or unconscious irony, decreed that the little Latin peroration should appear in reduced type-face! 
a flight from the realities of society and history. As Hans Dieter Betz wrote in 1969: 'To the apocalypticist "world history" in its entirety is identical with the "evil eon" and thus falls under that absolutely negative judgment... The apocalyptic view of history is indeed "indicative of a great loss of historical sensitivity" and has, in fact, dispensed with historical thinking. Accordingly, history cannot in this view possess any revelatory character. ${ }^{2}$ One response to this orthodoxy, which might prove attractive to someone who was interested not in apocalyptic in general but in this one New Testament example of it, would be to stress the distinctiveness of John of Patmos's book and the many ways in which it defies the generalisations which apocalyptic commonly invites. But this short way with the scholars is not necessarily the best. For the current orthodoxy, in my judgment, gives expression to certain prevalent conceptions which do in fact impede the reading of Revelation and exercise unacknowledged constraints upon what is commonly seen there. Of these I will identify two, taking as a representative sample of the consensus the 1971 article by Paul D. Hanson, 'Old Testament Apocalyptic Reexamined'. ${ }^{3}$

Hanson opposes two views of the world, the mythopoeic and the prophetic. The prophetic view 'recognised...divine activity as involving a movement from promise to fulfilment' and 'embraces the flux and movement of history as the arena of divine activity'; whereas myth 'offers escape from the change of the historical process' (p. 40). The birth of apocalyptic occurs when Deutero-Isaiah reintroduces mythic elements into the prophetic view of history, thereby resolving a difficulty in which the Deuteronomic tradition had become ensnared in the apparent hopelessness of the situation after the fall of Jerusalem. Subsequently apocalyptic moves more and more towards the mythic pole, draws man 'above the flux of the mundane sphere' to 'a salvation won on a timeless, cosmic level... The

2. 'The Concept of Apocalyptic in the Theology of the Pannenberg Group' in R. W. Funk (ed.), Apocalypticism (New York: Herder \& Herder, 1969) 201-202. Betz's quotation is from von Rad.

3. In Paul D. Hanson (ed.), Visionaries and their Apocalypses (London: SPCK, 1983) 37-60. 
dialectic between vision and reality began to break down' (p. 50). In classical prophecy, Hanson concludes, 'the realm of human history was the realm within which the covenant relationship between Yahweh and his people was being carried out; historical events were carriers of cosmic significance'. But in apocalyptic events are 'bound to an inevitable progression towards a predetermined end... The dynamic of...history...yields to the inflexibility of a history which becomes a timetable of cosmic events' (p. 57).

The first conception I draw attention to is the opposition of the categories 'mythic' and 'historical', upon which the effectiveness of Hanson's analysis depends. The success of classical prophecy lay in its ability to keep a perfect balance between them; but confronted with the fall of Jerusalem the tradition collapsed into pure history. Deutero-Isaiah tried to restore the balance, but his successors collapsed it in the other direction into pure cosmic myth. Now, it is not a sufficient objection to these categories that they are so plainly a modern version of the idealist polarity of a timeless world of ideas and a changing world of phenomena (a provenance which is strongly underlined when Hanson interchanges the categories of 'myth' and 'history' with those of 'vision' and 'reality'). For the interpretation of texts will always involve the use of concepts foreign to them. But it is important that the text should command the concepts and not the concepts the text; and here, it would seem, the conceptual apparatus has taken over completely. How else could Hanson fail to admit that for apocalypticists, too, 'historical events were the carriers of cosmic significance'? ${ }^{4}$ Biblical apocalyptic inherits (though it treats in a different way) the prophetic problematic of rendering events intelligible in terms of the purposes of God. The justification of history is its recurrent theme. It would seem undeniable, for instance, that the seer of Daniel was fascinated by the meaning of the succession of empires in world-history;

4. I welcome the recognition of this by Christopher Rowland (The Open Heaven [Iondon: SPCK, 1982] 38). Rowland seems to me to be on less secure ground when he argues his point from a supposed literal millennium in Revelation 20 (p. 435). 
but Hanson's way with that undeniable fact is to deny it. The succession of empires, he thinks, 'serves one function only in the vision, that of indicating the point when the cosmic event at the center of the vision would occur' (p. 55).

In Hanson's article we can detect also a second conception, which he has not clearly differentiated from the first though it is in fact quite distinct. History is characterised as 'flux', not only in opposition to the supposedly 'timeless' character of myth but also in opposition to the 'predetermined' character of events in apocalyptic. It is not at all clear to me that one can consistently accuse apocalyptic both of a determinist view of history and of a belief that salvation is timeless. The two charges would seem to exclude each other. But one can certainly maintain together the contradictory of both these positions, and insist both that history is the vehicle of salvation and that it is contingent and directionless. Such a view is easily recognisable, and belongs within the Augustinian mainstream of Western political thought, which, dominated by the image of the two cities, has drawn a clear line between secular and sacred history. Secular history, conforming to no shape and subject to no laws save those which follow from the perennially repeated clash between good and evil, is the locus of those sacred events which reveal the goal of man's existence; but it derives no perspicuous purposiveness from them. This distinction explains what sometimes appears to be almost a self-contradiction in the orthodox criticism of apocalyptic: its insistence both upon the meaningfulness of history as the bearer of cosmic significance and upon its character as undetermined flux. There is to be no evading the distinction between the revelatory character of the Christ-event, which declares the purposes of God, and the concealing character of all other events, which leave God's purpose a mystery.

The German scholars who have maintained views similar to Hanson's in the discussion of apocalyptic have been rather more aware than their English-speaking colleagues that their view bespeaks a definite position within a contemporary systematic debate. They are, in fact, acknowledged anti-Hegelians, opposed to the revival of the notion of an embracing world-historical purposiveness, a notion which they see as fundamental to apocalyptic though absent from classical prophecy. Hans 
Dieter Betz's article from which I quoted above was written as a shot across the bows of the Hegelian revival led by Pannenberg. An article early in the debate (1961) by Gerhard Ebeling contained an extraordinary four-page quotation from Kierkegaard (a sure sign that Hegel is under fire!) and included the following revealing summary of the position. 'The ground on which we are authorised to think God and history together in the right way (that is, differentiatingly) lies not in apocalyptic, but in the unapocalyptic fact of Jesus... Thinking God and history together in the name of Jesus leads of necessity to a criticism of apocalyptic, certainly not in the sense of a reinterpretation of apocalyptic in terms of a concept of revelation and universal history that is of Hegelian provenance, but in the sense that through his word God manifests his power over history by putting an end to the power of history. 5 Ebeling brings out as clearly as anyone could the Augustinian secularist terrain on which the objectors stand - the right way to relate God and history is to differentiate them, not permitting history to pose as the messenger of the covenant. The one and only place at which history becomes such a messenger is the unapocalyptic fact of Jesus - unapocalyptic in that he does not communicate a general cosmic teleology. The import of the Christ-event for history is not positive but negative, in that it puts an end to its power. The mistake of apocalyptic is to think that it can resolve the opposition of God and history dialectically, and so tame history as God tamed Leviathan, creating a construct of world-historical order which is an 'escape from history' in a different sense - that is to say, that it does not face the scandal which history poses for faith. 'Canst thou', we may imagine Ebeling demanding of John of Patmos, 'draw out Leviathan with an hook?'

The association of Hegel and apocalyptic is instructive. For Hegel is usually seen as the only-begetter of the modern concept of history, which has famously been responsible for the doctrines of Marxism but which also deserves credit for transforming Western liberalism into a creed of progress. But behind Hegel some observers have thought to discern a subterranean channel running back through radical Protestantism, and through the millenarianism of the late middle-ages, to the seminal

5. 'The Ground of Christian Theology' in Funk (ed.), Apocalypticism 64. 
doctrine of Three Ages promoted by Joachim of Fiore; and Joachim thought that he was interpreting the Book of Revelation. ${ }^{6}$ Are we, then, to believe in a countercultural tradition of political thought within Christendom, historicist in character, taking its root from John of Patmos and bursting into belated prominence in the nineteenth century, an alternative to the orthodox Augustinian secularism of the West which takes its root from Paul? It is an appealing hypothesis at first glance; but the truth is more complicated. Augustinian secularism, too, is founded on a philosophy of history, albeit a philosophy of sacred history. Furthermore, the two-cities concept on which Augustinian political thought rests has no New Testament source more immediately striking than the Apocalypse of John. We should rather say that the two-cities concept gives rise to two different streams of interpretation - a secularist one which emphasises its negative implications for the teleology of secular history, and an apocalyptic one which understands world-history in terms of the ultimate disclosure of the mystery of evil. But both streams are differentiated from the monist interpretation of society revived by Thomas Aquinas as a result of his rediscovery of Aristotle. The two-cities concept does have a commitment to understand the human good as social, and in this respect stands apart from pure Neo-Platonism; but it is only eschatologically social, and sociality is only eschatologically an unambiguous good, and in this respect it stands apart from Thomist Aristotelianism. Augustine severed the link between historical society and human virtue almost as self-consciously as Thomas stitched the two together again. ${ }^{7}$ Placed against this grid, Hegel appears as a historicist variant of the Aristotelian-Thomist tradition. Are we, then, left with a parallelogram of possibilities: John of Patmos sharing historicism with Hegel and the two-cities view with Augustine; Augustine sharing a non-teleological, secularist view of history with Thomas, while Thomas in turn shares a monist optimism with Hegel? Such a schema will serve merely as a hypothesis, to focus the questions.

6. See Erich Voegelin, 'Ersatz Religion' in his Science, Politics \& Gnosticism (Chicago: Regnery, 1968) 81-114.

7. See R. A. Markus, Saeculum (Cambridge: CUP, 1970) 211-230. 
Within modern Christian political thought the Augustinian secularist stream has yielded a policy of involvement in social and political tasks, which presumes upon the opacity of secular history to ultimate values and hence upon the neutrality, in moral and spiritual terms, of the political realm. For the mainstream Western thinkers politics has been, as it were, an open space, ready to be occupied equally by those who would do evil and those who would do good to mankind. They have developed, therefore, a concept of practical Christian cooperation in the political arena which neither hopes for too much nor fears for too much. In distinction from this we find not only the 'ideological' idolisation of the political realm, of Hegelian inspiration, which understands public history in semi-religious terms, but also the apocalyptic conception of public history as a manifestation of evil. This conception invites the objection, from secularist thinkers who regard themselves as taking history seriously, that it is antihistorical in its stance. It is at least arguable, in reply, that it is to take history no less seriously, and possibly more seriously, if one reckons with its inbuilt structural commitments. But if such a reply is to be made good, there has to be an alternative way of engaging with public affairs which does something better than simply cooperate on the one hand and avert the eyes on the other. Criticism is the form of political engagement which emerges as normative within the apocalyptic perspective. Criticism has the advantage, as its proponents see it, of illuminating the course of history by the word of God, yet without pretending to master history or even exploit its supposed neutrality, but pointing to the mystery of the ultimate triumph of the divine word as the object of its hope. The apocalyptic political thinker calls into question that busy enthusiasm for cooperative endeavour under the shadow of Leviathan, returning the challenge which the Augustinian addressed to him before. 'Wilt thou play with him as with a bird?' The issue between the two approaches can be brought down to this: Is criticism a valid engagement with the public realm, and is any other engagement realistically possible? It is not surprising that where the claims of criticism against cooperation are advanced most strongly, John of Patmos is deemed to 
be politically significant. This conviction unites such otherwise irreconcilable points of view as those of Jacques Ellul and the liberation theologians of Latin America. ${ }^{8}$

One thing must be made clear, and that is that John's interest in history is by no means simply an interest in particular events that are occurring around him. In my opinion, the number of particular historical references in the Book of Revelation is two. They are found at 13:18 (the number of the beast) and at 17:9-11 (the meaning of its seven heads). If these references were removed, the surrounding material would require little or no editing to preserve its sense, which simply goes to show how little structural weight they carry. John's unfolding of the mystery of evil proceeds not by journalistic documentation but by theological principle. These two definite identifications arise as illustrations of the principle. Compare John's reference to Nero (as I take it to be) with Hegel's famous remark that the universal and homogeneous state would come first into being in America. If that particular prophecy were falsified (or should we say, if it had not been verified?) it would not invalidate Hegel's general reading of political development; the identification merely added to the verisimilitude of the general construction. This is not to deny, of course, that John's understanding of history was influenced by what he saw happening before his eyes. Biblical historians have accumulated a mass of examples, plausible and implausible, of how John's imagery may have been shaped by first-century events. To take an old example: the activity of the false prophet, the beast from the land in chapter 13, may indeed have been suggested by the activities of the Commune of Asia, as commentators, following Sir William Ramsay, have united in affirming. But it would be quite wrong to conclude that the beast from the land represents the Commune of Asia. John has nothing definite to say about that body;

8. J. Ellul, L'Apocalypse: architecture en mouvement (Paris: Desclée, 1975). For the use of Revelation in the liberationist tradition, see Juan B. Stam, 'El Apocalipsis y el imperialismo', in Capitalismo Violencia y Anti-vida, ed. E. Tamez and S. Trinidad (San Jose: Dei-Educa, 1978). I am indebted for this reference to Thomas Hanks. 
but he has a great deal to say about the way evil propagates itself as false worship. ${ }^{9}$

Before I embark upon exposition, a word is in place about how I judge the Book of Revelation should be read. In recent generations commentators have learned to take John of Patmos seriously as a theological spokesman for first-century Christianity, whose apocalyptic imagery is a disciplined and intelligible theological language. 10 Two features of this language have sometimes proved troublesome to interpreters. One is the use of sequence to achieve theological analysis, so that the same phenomenon is presented more than once, each time from a new angle. The core of John's Apocalypse is a sequence of three cycles of seven disasters. Each of these cycles shows us the same thing, the degenerating course of history; but they show us it from different points of view, so that in the last cycle we have come to see how history manifests divine judgment. ${ }^{1}$ Another example concerns the notorious 'millennium' of 20:4. John has two last battles, two resurrections, two acts of judgment, the one culminating in the thousand year reign of the saints, the other in the judgment of the great white throne. The first series shows the victory of the true Messiah over the false, the second the victory of the Father over the aboriginal dragon. Everything is

9. This distinction, not always well understood by Biblical historians, is nicely made in some lines by Robert Frost:-

Samoa, Russia, Ireland I complain of, No less than England, France and Italy.

Because I wrote my novels in New Hampshire Is no proof that I aimed them at New Hampshire.

10. Among those who taught us this lesson, I, like others, must confess a special debt of gratitude to the late George B. Caird, whose commentary (The Revelation of St. John the Divine [London: A. \& C. Black, 1966]) taught me how to read the Apocalypse.

11. John M. Court (Myth and History in the Book of Revelation [London: SPCK, 1979] 48) invites us to choose between a 'recapitulation theory' which 'asserts that the seven bowls reflect exactly the same events as the seven seals' and a 'chronological theory', in which there is 'a clear distinction between sequences". I confess that I do not know how to make this choice, since the prophet's concern, as it appears to me, is not with 'events' so much as with the shape of history as a whole. 
shown twice because we must understand that the kingdom of Christ is the kingdom of the Father. It is a kind of reflection on the resumption of the Messianic authority suggested at 1 Corinthians 15:28. I do not believe that John intends to prophesy a this-worldly millennium which is distinct from the reign of God in the new heaven and the new earth; rather he intends to say that the vindication of this-worldly justice and the fulfilment of this-worldly history are included in the reign of God in the new heaven and the new earth. ${ }^{12}$ Lest we should conclude that the exercise of Messianic authority is actually confined to a stated number of years, John complements this sequential presentation with another, in which the throne of God and the Lamb is one throne, and in which the servants of God, who were earlier said to reign for a thousand years, now reign 'for ever and ever'

12. It is conventional, and not unjustified, to see the origins of the millennium in the need to reconcile two traditional pictures of the end. Thus H. Kraft writes: 'Im apokalyptischen Judentum bestanden nebeneinander zwei Enderwartungen: die nationale, die ein messianisches Reich nach siegreichem Glaubenskrieg erhoffte, und die universale, die meist mit einer Rettung der Gerechten durch Weltuntergang und Neuschöpfung hindurch rechnete. Obwohl diese beiden Auffassungen miteinander und mit der Eschatologie nichtjüdischer Religionen in jeder erdenklichen Weise Verknüpft wurden, empfand man sie doch als grundsätzlich verschieden. Es gehört zur Methode der späteren Prophetie in solchem Fall nicht kritisch zu sichten, sondern zu addieren, und so wurde das Zwischenreich der universalen Auffassung vorgeschaltet' ('Chiliasmus', $R G G^{3}$ 1.1651). What this account fails to register, however, is that the millennium in Rev. 20:4 is more than a palaeological deposit from a past conflict of apocalyptic expectations, but continues to mediate between two complementary visions, both of which have living significance for the prophet, and which converge in his Christian understanding of the Messianic kingdom as one with God's. 
(22:5). This illustrates the second feature of John's language of imagery which can prove puzzling: images are dialectically superimposed upon one another, without resolution of the tensions that they generate.

With these introductory observations I shall venture upon an account of the political thought of the Book of Revelation.

We begin from the question which the prophet articulates decisively at the beginning of his apocalypse proper: why and how does history impugn the excellence of creation? In chapters 4 and 5 he shows us a tableau of creation, in which the throne of God is surrounded by the symbolic representatives of the created order, ceaselessly offering their praise. But their hymns are interrupted by the discovery of a sealed scroll in the hand of the Most High. As a scroll, it represents a history; as a sealed scroll, its contents are unintelligible to us. So the prophet poses his problem: how can the created order which declares the beauty and splendour of its Creator, be the subject of a world-history, the events of which are directionless and contradictory? The goodness of creation is impugned by the meaninglessness of events. Only if history can be shown to have a purpose, can the prophet's tears be wiped away and the praise of the creation be resumed. We can all repeat the words in which the consolation of the Gospel is announced to him: 'Weep not; 10, the Lion of the tribe of Judah, the Root of David, has conquered, so that he can open the scroll and its seven seals.' And then, as the prophet tells us unforgettably: 'I saw a Lamb standing, as though it had been slain' (5:5-6). The sacrificial death of God's Messiah is the event to interpret all events, which alone can offer human existence the cosmic meaning which it demands. It provides the justification of creation in history, and the justification of history in new creation.

With this announcement of his theme the prophet launches into the first of his three cycles of seven: the seven seals, the seven trumpets and the seven bowls, which, as I have said, show us the whole course of history, seen as tragic necessity, three times over, each 
time from a more profound perspective. In between the second and the third of these cycles John places the central episode of his book, around which all turns, the encounter between the two Christs, the false and the true. The cycles of seven follow a common formal pattern: the Lamb breaks the seven seals, the angel blows the seven trumpets or pours out the seven bowls; and after each something happens. In the first four of each cycle it is always a natural or political disaster. With the fifth and sixth of each cycle the character of the event changes, to expose some aspect of moral or spiritual evil. The seventh of each cycle represents the victory of God over the evils of historical necessity - yet the victory is at the same time the climax of all the evils, because it is the exercise of divine judgment, in which divine wrath overwhelms human wrath (cf. 11:18). However, it is not until the third cycle, the cycle of the bowls, that John is ready to show us divine victory emerging immediately out of the historical process, for not until then has he shown us how the course of historical necessity has itself from the beginning been an expression of the divine battle against the emissaries of the primaeval serpent, the devil. In the first two cycles, then, the concluding item of victory has to be presented as it were, through a mirror, as visible only indirectly to faith and not yet fully disclosed. And this is done by a simple structural device which has caused confusion among John's readers, commentators, and even among editors of the biblical text. The content of the seventh seal and the seventh trumpet is placed before, not after, the actual breaking of the seal and sounding of the trumpet. So the cycle of the seals ends mysteriously: 'When the Lamb opened the seventh seal, there was silence in heaven for about half an hour' $(8: 1)$. And with that silence, the silence of history held back from its tumultuous rush, the silence of a pause imposed before the end should come, the cycle ends. (Not only the traditional chapter division, but also the paragraph divisions of our modern Bibles show how little John's impressive effect has been appreciated!) But that is because the content of that mysterious silence has already been shown to us, in a long vision placed immediately before the breaking of the seventh seal which seemed to interrupt the sequence. The content of that vision explained the form: the four winds were held back, the command was given to restrain the forces of judgment until the servants of God should be sealed on their 
foreheads $(7: 1-3)$. The first cycle, then, shows history concluding in an ambiguous and unearthly hush which (secretly, and as though in a mirror) we are told is the suspension of historical necessity which God has willed for the gathering of the elect. Something similar occurs at the end of the cycle of trumpets.

So much for the common structure of the three cycles of historical necessity. What does John mean to show us through them? And why does history take the form of tragic necessity? Each cycle offers a different answer to this question, of which the first, the answer of the seals, is the most sceptical and the least profound. As each of the first four seals is opened, a horse and rider gallop across the scene: the first horseman carries a bow, and wears a crown of victory; he goes forth, we are told, 'conquering and to conquer' $(6: 2)$. The second holds a hasta longa and has the power to remove peace from the earth 'so that men should slay one another' $(6: 4)$. The third carries in his hand the yoke of slavery, and is accompanied by a voice which complains about the shortage and expense of necessary commodities 'but do not harm', it adds ironically, 'oil and wine', the luxuries $(6: 6)$ ! The fourth is named Death and Hades, and causes devastation in the earth through slaughter, famine and plagues of wild beasts. Clearly this sequence of disasters is a progressive sequence, the catastrophe growing worse at each step. And clearly it is intended to be a sequence of events which are politically initiated. War is its starting-point, the confident knightly enterprise of ambitious conquest, for which war is a means of glory and renown; but in its train comes the unleashing of recrimination, civil strife, shortage of supplies, and finally the imperilling of social existence by depopulation and starvation.

One may learn a lot about the character of any tradition of political thought by identifying the activity which it sees as the central paradigm of politics. For Thomas Aquinas it is the founding of cities; for st. Paul and Augustine it is the punishing of wrongdoing. For the prophet John, at this stage of his analysis at least, it is conquest in war. From the adventures of the first horseman who wears the crown there springs an inexorable chain of political and social evil. The fifth seal takes the sequence into the realm of justice by disclosing the unsatisfied cry for 
vindication which goes up to God from the afflicted righteous; and the sixth evokes the atmosphere of dread and impending disaster which characterises international politics (of the twentieth as well as the first century): kings, potentates and commanders cowering in fear before the judgment that their own ambitions have unloosed, trembling under the weight of responsibility. Yet we would misunderstand John's intentions if we were to think of him as offering us a theodicy of an Augustinian type founded in the fall of the human will. The chain of historical necessity is also a chain of natural necessity. The four horsemen are summoned, not only by the Lamb's breaking of the seal, but by a summons from one of the four living creatures out of the vision of creation. That is to say: it is the forces of nature which have produced this deteriorating spiral of human political strife. The enterprise of conquest, destructive both to nature and to society, has itself arisen from natural impulses and energies. That is the puzzle of nature and history as the prophet conceives it. Nature seems to carry within itself the seeds of its own destruction; and political strife is the fatal overspilling of natural energy which must disrupt nature and bring it to nothing.

13. Our understanding of the sequence of seven seals departs from the more common interpretation of it as a development of the tradition of 'signs of the end' found also in the synoptic apocalypses (Mk. 13 and par.) (See Court, Myth 43-81.) This yields a more church-oriented reading than the one we have followed. The horsemen of the first four seals represent events from the turbulent first-century background of the church's life, the martyrs of the fifth seal become the early Christian martyrs, of whom the synoptic apocalypses speak. Without wishing to deny a measure of formal dependence of John's material upon that of the synoptic tradition, I would pose two questions to those who find this an adequate account of what we read in the sixth chapter of Revelation. Does it do justice to chapter 5, with its carefully delineated setting of the sequence of seals in the context of a cosmic problem? For it is not enough to say, with Court (Myth 55), that 'the seer expresses very precisely the fact that his perspective begins with the crucifixion of Christ', when the scroll of history was held in the hand of the enthroned King, and was already a source of 
In the cycle of seals, therefore, we are left with a simple demonstration of the problem of creation and history: the final stage, the vision of the elect before the heavenly throne, appears rather as a suspension of historical necessity than as a reconciliation of it. But in the cycle of trumpets a new perspective is added: the initiation of the chain of evils lies not with the forces of nature, but with the prayers of the saints which ascend from the altar of sacrifice. The disasters - which in this cycle are natural, not political - are called forth by the demand of outraged justice given voice through the prayers of the righteous. And then in the cycle of bowls the initiative is transferred again: it comes from God himself, speaking out of his heavenly temple, so that the disasters, which remind us of the plagues of Egypt, are imposed directly by the activity of divine providence. Through the three successive cycles, then, we come progressively to see how divine initiative lies behind the degenerating horrors of history, which appear, at first blush, to be a failure of the created order of nature.

Let us pause over the term 'necessity', which I have used to characterise the tragic history which the cycles of seven disclose to us. Necessity is an appropriate term, because it has traditionally been used by philosophers in an ambivalent way, to point to a distinctive coincidence of good and evil. Necessity is, on the one hand, constraint, which deprives us of the freedom in which our fulfilment in the good is achieved. On the other hand, it is order, which ensures the sovereignty of the good by ruling out randomness and arbitrary meaninglessness. Thus the sequence of cycles contains a part of the answer to the problem posed by the sealed scroll. We are invited to read the inscrutable legend of history by conceiving its tragedy as inexorable constraint; but even in inexorable constraint we can learn to see justice and the hand of

13. (contd.)

anxiety to mortal men before ever the Lamb appeared to open it. And in the second place: has it given a satisfactory account of the climax of the sequence in the vision of the seventh chapter, where the redeemed are carefully identified, first of all, as the faithful of the old Covenant, drawn from the twelve tribes of Israel? 
God. Already in this conception the threat of sheer arbitrariness is set at a distance, and the good, distinctly, if not unqualifiedly, is present.

This, however, can only be a partial answer. For although order (and so goodness) is vindicated in the act of judgment - so that we can speak of 'satisfaction' in judgment, and can be aware of an existential need for it - nevertheless, where order is imposed at the cost of freedom, then the good of creation is vindicated only negatively: it is not vindicated positively in flourishing and perfection. A universe in which sinful existence is cancelled out by the divine wrath has a kind of formal rightness; yet it is not worthy of a creator to accept such a vindication. (Here, of course, we touch upon the famous 'divine dilemma' which drives the theology of atonement as it was worked out by Athanasius and Anselm.) What place, then, is allowed for freedom in this presentation of historical necessity as divine justice?

In the first place we see freedom exercised in prayer. The afflicted righteous who, at the fifth stage of the first cycle, cry out from beneath the altar, 'How long before thou wilt judge?' $(6: 10)$, are told to wait, not merely for the maturation of divine purposes which concern others than themselves, but that their own freedom may be realised in the activity of prayer itself. When we first hear that prayer we hear it only as a cry of impotence. But at the start of the next cycle, we are shown that it is a prayer of power; for it is this prayer, and no other, which the angel mingles with the incense on the altar, so that it rises in the smoke of the incense before God $(8: 3)$; and so it is this prayer which, when cast as fire from the altar upon the earth, sets loose the thunder, lightning and earthquake of the seven trumpets. In the second place, freedom is exercised in prophecy. Here we touch on a theme close to John's heart, for it is the theme of his own vocation. The seventh stage of the second cycle - the stage which tells of divine victory, and which precedes, but belongs to, the seventh trumpet - is a vision of two witnesses who prophesy in God's name with great authority, are slain, and are raised to life again by the power of God. The believer, then, exercises freedom in speech: the speech of prayer which addresses God from the affliction of historical necessity and the speech of prophecy which addresses mankind in the authority of God's word and which triumphs over necessity. 
Creation is vindicated in two ways, we conclude: by the immanent judgment of God worked out in the course of historical necessity, and by the overcoming of necessity by the power of the believer's true speech. So much of an answer to the initial question has been given us by the end of chapter 11, the climax of the cycle of seven trumpets. But it is a dialectical answer, which has not been resolved; necessity and freedom have not been reconciled. The realm of politics has been associated with the sphere of necessity, and freedom has been represented in an anti-political way. This impression is reinforced in the vision of the two witnesses by the use John makes of the 'great city, which is allegorically called Sodom and Egypt, where their Lord was crucified' $(11: 8)$. The city - that pregnant symbol, which we here meet for the first time in the Apocalypse - is the concrete definition of the human urge to conquer when confronted by the prophetic rebuke of the Word of God. Conquest has assumed a permanent form; it has embodied itself in a political institution, which is opposed to the freedom of the word of truth. Politics is poweragainst-the-Word. Yet John has not neglected to drop a hint for us (who have not yet reached the conclusion of his vision) that another view of the city is possible. The vision of the two witnesses began with the solemn measurement of the temple of God, which was to be kept safe by divine protection while the city around it, 'the holy city' (11:2), was trampled underfoot by the nations. This 'holy city' is the same as that which is called Sodom and Babylon, and (though John will not grant it the dignity of the name. Jerusalem) is the city in which Christ was put to death. The political institution which appears as the embodiment of opposition to the truth may be something else: it may be the holy city given over to desecration. Beneath the phenomenon of power-against-the-Word there is the deeper political reality of a community consecrated to the Word. We are at least permitted to anticipate that the politics of conquest may be countered at the last by an alternative politics of worship.

At the beginning of chapter 12, introducing the great central section of the Apocalypse, John presents an allegorical narrative of the birth and triumph of Christ. This is of great importance for our understanding both of what has gone before and of what is to come 
after. The content of the first two cycles has been enacted, as it were, ante Christum natum, or at least remoto Christo. The souls of the righteous under the altar were not necessarily the souls of the Christian faithful, but simply the souls of righteous mankind; the two witnesses who prophesied in the great city were not presented as Christian witnesses, but as figures from the old Testament, the olive-trees and lampstand of Zechariah, 'the two anointed who stand by the Lord of the whole earth' (Zc. 4:14), slain in the appropriate city where every prophet must perish. Of course, it goes without saying that the course of history as seen in these two cycles reaches its climax in 'the kingdom of our Lord and of his Christ' (11:15). We could expect nothing less since it was the Lamb who opened the seals. But only at the seventh stage of each cycle is a distinct reference to Christ introduced - the gentile multitude who 'have washed their robes and made them white in the blood of the Iamb' $(7: 14)$, the two prophets slain in the city 'where their Lord was crucified' $(11: 8)$. It is the dawning of the kingdom that reveals how the righteous have, in fact, been serving christ all through the vicissitudes of an oppressive and apparently meaningless history.

But it is equally important that what follows should be understood to belong post Christum, in the Messianic age. John's vision proceeds from the taking-up of the Messiah into heaven, to the expulsion and fall of Satan, the persecution of the church, and then to the memorable passage which is most often alluded to by those who wish to characterise his political outlook with a single stroke of the brush, the summoning of the beasts from the sea and the land, which herald the oppressive and idolatrous totalitarian order described in chapter chapter 13 .

We should reflect on John's intentions in situating this passage of political criticism at this point. Initially it may surprise us that he should conceive political theory in relation to salvation history. The Western tradition derived from Augustine does not do this: it understands politics in terms of the providential dispensation post lapsum, in the light of the covenant with Noah (and, of course, John does not propose to contest a relation between politics and providence, as the cycles of seals and trumpets can 
verify). But he wishes to identify something distinctive about the shape of politics in the Messianic age, between the Ascension and the Parousia of Christ. In this respect his approach will bear comparison with the account of governing authorities given in Romans, 1 Timothy and 1 Peter. For although these passages are important sources for the Augustinian view, they also display (of Romans and 1 Peter at least this can be said) a marked eschatological emphasis. If we are inclined to say that John's interpretation of politics is apocalyptic, while that of the Pauline strand in the New Testament is self-consciously secular, we may do so innocuously - provided that we add that even the secular approach ('every human institution', 1 Pet. $2: 13)$ takes its rise from the expected 'day of visitation' $(2: 12)$. The Pauline tradition, too, knows that we stand between the Ascension and the Parousia of Christ, that 'the night is far gone, the day is at hand' (Rom. 13:12), and that our thought about politics begins with the admission that the claim of lordship has been appropriated to himself by the ascended Christ. The implication of this is that believers pray for 'a quiet and peaceable life' under their kings (1 Tim. 2:2); whereas John expects those same prayers to let loose an idolatrous this-worldly empire.

John's image of blasphemous empire is that which was common to Jewish apocalyptic writing from the Book of Daniel onwards. There arises a beast from the sea; the sea, here as elsewhere, represents the abyss of chaos and disorder which was overcome in the divine act of creation. The changes that John introduces into the picture of Daniel chapter 7 are as important as the points of resemblance. John's one beast combines the characteristics of Daniel's four. He is not, like Daniel, propounding a world-history of empires, in which each of the successive great powers, past and present, has a place. He is aware that there is such a history (and will draw upon it later in his treatment of the Great Whore) but he is not concerned to trace it. His interest, rather, is in empire as an eschatological phenomenon, evoked by the diabolical fall which follows upon the triumph of Christ. The order of events in Daniel 7 has thus been turned significantly upon its head. Where the old Testament prophet saw a sequence of historical empires being brought to a close by the exaltation of the Son of Man, the New Testament prophet 
sees demonic empire as evoked in a new, though temporarily limited, form precisely by the exaltation of the Son of Man.

John's beast differs from Daniel also in its relation to the dragon, 'that ancient serpent, who is called the Devil and Satan' (12:9). Daniel's four empires emerge in sequence from the abyss of their own accord, whereas John's beast is summoned by a force more primaeval and fundamental than itself, which it resembles not only in the possession of ten horns (which they both share with Daniel's fourth beast) but in the possession of seven heads. The native element of the dragon was heaven. Cast down by the triumph of the Christ, he looks for an earthly form in which to operate, and that form is empire. In various ways the prophet suggests that the relation between the dragon and the beast is a parodic reflection of the relation between God the Father and the Son. The dragon confers upon him 'his power and his throne and great authority' $(13: 2)$ in an imitation of the enthronement of the Messiah. We have already remarked that at the end of the Apocalypse evil is overthrown in two stages: the beast by the victorious Messiah and the dragon by the all-judging Father. And now we may also notice the feature of the healed wound, by which the beast parodies the death and resurrection of Christ; it is a symbol of his Messianic status. And we need not invoke Nero Redivivus to explain it; we need look no further than the phenomenon of empire itself, which looks as though it brings life out of death. By imposing order upon chaos empire seems to introduce the promise of resurrection into human affairs. Throughout John's presentation of the beast and its empire we find him absorbed in the pretensions of evil to provide a positive focus for social unity and cohesion. At heart, he believes, evil is simply self-destructive and provides no ontologically secure basis for social life. Yet in the phenomenon of empire it appears to provide a secure basis. And John's criticism of that appearance is that it is parodic and derivative. It achieves what it appears to achieve only by crude imitation and distortion of the good. Thus the authority of the beast is established by the names of blasphemy which it bears, a parody of the one who has authority by bearing the divine name before mankind. The divinity of empire is a borrowed divinity. 
Parodic imitation is carried further with the appearance of a second beast, the beast from the land, who is also called the 'false prophet', accompanying the false Christ in literal fulfilment of Mark 13:22. Although the second beast is described in details from Daniel 8:3, its immediate source is in the later apocalyptic tradition (cf. 2 Esdras 6:49ff., 1 Enoch 60:7-8, 2 Baruch 29:4) which speaks of two beasts, Leviathan and Behemoth, one from the sea and one from the land. But John's real interest is in developing a trinitarian account of empire as idolatry. His enlargement of the Father-Son relation into a trinitarian one is quite self-conscious. Although the person of the Holy Spirit is not explicitly mentioned in the Apocalypse proper until almost the last verse, John is continually alluding to the Spirit's role by stressing the place of true prophecy in the church's witness. As he wrote in his introductory letters: 'He who has an ear, let him hear what the Spirit says to the churches' (2:7 etc.). The beast from the land is also the false prophet. Unlike Daniel's he-goat, he speaks. It is his essential raison d'être to speak, to act as the ideologist of the empire and to support his speech with miraculous signs, so becoming the prophetic voice which maintains the empire's legitimacy and persuades mankind to adhere to it. John knows that though the essence of empire may be conquest and the denial of true speech, that empire which is falsely Messianic must depend upon the concealment of its essence with a plausible appearance of true speech, which is in fact false speech. The authority of falsehood is of critical importance to the Antichrist's regime; but the only authority which falsehood has, is that which it has borrowed from truth.

The false-prophet maintains the claim of the Antichrist to possess his subjects wholly, as Christ possesses his saints, by a parody of the baptismal seal. In the light of twentieth-century experience, we are fond of seeing here a description of what we call 'totalitarianism', and this is not mistaken. Totalitarianism is the assumption of all independent authority, natural or spiritual, the authority of the parent, of the teacher, of the priest, of the artist, into one authority of the state. But underneath the evil of totalitarianism, as John would show it to us, lies the more fundamental evil of Messianic ideology, the claim to ultimate allegiance. By presenting itself as the 
emissary of God, and demanding of its members the adherence appropriate only to the church, the empire brings the final condition of Hell into history. It provides a concrete form in which mankind can give himself heart and soul to a community of evil. Thus the mystery of evil serves the divine purpose of final separation.

Here we can only underline the contrast with the Pauline tradition. The state of government for which Christians are commanded to pray is one in which there is space, 'a quiet and peaceable life' (1 Tim. 2:2), space for the question of ultimate allegiance to be raised and answered in the preaching of the Gospel. Such a state is neutral at the ultimate level, however committed it may be at the penultimate. John does not challenge the suggestion that we ought to pray for such a space of freedom and neutrality. Yet he does not expect that prayer to be granted in the form in which it is made, not, at least, for more than intermittent periods. Under the force of the Gospel and of the allegiance to Christ which it evokes, the state comes to demand an opposite and ultimate allegiance. The mutual exclusiveness of the separation of good and evil begins to assume a shape within history. Those who do not worship the beast are thrust out from the market, which (for the first century as for the nineteenth) is the place of morally neutral political relations, the place of commerce without commitment. The closure of the market on ideological lines is a sign of the separation of the communities. Yet even that development, John would tell us, the very opposite of what we have prayed for, the failure of the liberal market to sustain itself under the clash of ultimate claims let loose upon the world by the ascension of Christ, is, though we could never bring ourselves to pray for it as such, God's most direct route towards that day when all our prayers for justice receive their truest answer.

\section{III}

It is one of those prima facie puzzles with which John confronts his interpreters that he has two dominant images for empire and not just one. After the reign of the beast from the sea and the false prophet, who represent the Messianic pretensions of empire in the Messianic age, we meet in chapter 17, in the first of three major concluding visions of judgment and triumph, the Great Whore. And as though to prevent his 
interpreters from evading the puzzle which he has set for them, John sets the Whore riding upon a beast which (as we are meant to have no doubt) is precisely the same beast that we have already encountered, still rising from the abyss $(17: 8)$, despite the curious feature that it has now acquired a scarlet coloration.

My own suggestion for understanding this dual imagery is that the beast represents empire quite specifically as a phenomenon of the Messianic age, evoked by the triumph of the true Messiah and the limited dominion of the devil upon the earth. But empire as such had been a longstanding feature of the Mediterranean world. The prophet had, therefore, to admit a distinction between empire as a permanent feature of world politics and the eschatological heightening of empire - we might say, its demonisation - which marked the age of the church. The representative of world empire in the Old Testament was Babylon; and in introducing the figure of the Whore, whose name is Babylon, John intends to emphasise the continuity between the ancient prophets' experience of empire and the contemporary experience of Christians under the dominion of Rome. It is, of course, absurd to suppose that the name Babylon was merely a device for concealment. When John points out that this Babylon sits upon seven hills, the hint he drops is so heavy that it would surely be sufficient to earn him a further spell on Patmos if it were to come to official notice! The name is theological: it recalls the prophetic understanding of the Mesopotamian empires, and John uses it as an interpretative key to the rise of the Roman empire. Thus the Whore is not Rome stricto sensu. She is human empire as such, which is presently situated at Rome, on the seven hills. Or, more concretely, she is Babylon transferred to Rome. She is an old familiar figure, well known to the reader of the prophets, who has been brought out of retirement by a new patron (of whose demonic origins she is blissfully unaware) and has been set up in a new home, to be used for ends which she cannot begin to understand. Thus John is able to study the political situation of his day from another angle, examining the general features that it shares with the empires of the past, without withdrawing from the particular claims he has made for the apocalyptic character of empire in the Messianic age. And of course he wishes to stress that empire, simply as a secular phenomenon in human politics, has a fate that 
is due to it, as the prophets of old had said long before. The Great Whore is to be destroyed by her lovers. For the beast himself, however, there is a very different end in store.

Already in chapter 14 John has heard some words recalled from the Isaianic apocalypse (Is. 21:9), proclaimed by one of the three angels entrusted with preaching the 'eternal Gospel' to the earth: 'Fallen, fallen is Babylon!' The fulfilment of the prophets' hope for the end of imperial bondage is already a part of the Gospel which the coming of Christ preaches to the world. The particular form of the prophetic quotation at 14:8 deserves close scrutiny. Nowhere is John more careful and subtle in his use of old Testament material than in his presentation of Babylon. The words from Isaiah 21, 'Fallen, fallen is Babylon!' are immediately followed by others from the Babylon oracle in Jeremiah 51: 'who has made all nations drunk with her wine'. But into this quotation again John weaves some further words, describing the wine as 'the wine of the wrath of her fornication'. Now, when we first hear these words, their bearing seems evident enough. The wrath is the wrath of God, manifest in the sudden growth of the Chaldaean empire, and all nations have been made to experience the impact of divine wrath through Babylon's 'fornication', that is, her indiscriminate conquests. But when the words return, slightly amplified, at 17:2, the reader suddenly awakes to what the author has done. He has woven into the tissue of Babylon quotations an allusion to the prophecy against Tyre at Isaiah 23:17. 'At the end of seventy years, the Lord will visit Tyre, and she will return to her hire, and will play the harlot with all the kingdoms of the world upon the face of the earth.' But this immediately puts a very different complexion upon that 'fornication'. For the fornication of Tyre is not indiscriminate conquest, but promiscuous trade. And as we read John's mighty lament over Babylon-Rome which occupies chapter 18 of the Apocalypse, we find that it is composed in about equal parts of allusions to prophetic oracles against conquering Babylon and against trading Tyre. The two major sources are Jeremiah 51 against Babylon and Ezekiel 27 against Tyre. Details of the Babylon prophecy take on a new significance as they are associated with Tyre: the 'many waters' on which the harlot sits, for example, were (in Je. 51:13) a reference to Babylon's elaborate 
canal system; but now they are evidently intended to represent the Mediterranean Sea, on which the great commercial city plies her trade.

What are we to make of this? It is possible to see it merely as a happy use of diverse materials in order to characterise more precisely the hold which Rome has upon the nations of her empire, a hold very much rooted in commercial and cultural exchange and by no means merely a matter of military force majeure. I cannot help thinking, however, that this would be to underestimate our author. It is not for him a purely circumstantial matter that the new Babylon has learned the arts of old Tyre; nor is his use of the image from Isaiah 23, describing trade as 'fornication', merely decorative. The significance of this marriage of Tyreand Babylon-motifs is that trade, too, as much as conquest, violates the integrity of communities which become dominated by the cultural influences of the stronger trading power. We have to recall that the tyranny of the beast in chapter 13 was exercised through control of the market. In that sense trade is

'fornication'. It is a cultural promiscuity by which one power exploits and drains the resources from many others. John stands preeminent among those who have seen mercantile enterprise as a tool of empire. He reserves for the very conclusion of his lament on Babylon-Rome a quotation from the Tyre oracle, Isaiah 23:8, to which he gives great prominence: 'Thy merchants were the great men of the earth' $(18: 22)$. Less striking to us, perhaps, than to the ancient world is the thought of a society in which the rulers are merchants and the merchants rulers - the paradoxical scene which confronted the astonished Israelite prophet when he looked upon Tyre. Yet he saw nothing so paradoxical as a world empire in which this was so. But for John this paradox was the key to the power of the world-empire in which he lived. It ruled over the multitude of nations by exercising commercial and cultural monopoly.

In Ezekiel's lament over Tyre the seafaring classes, who have become rich by Tyre's greatness, wail and weep at her fall; while the 'merchants among the peoples', on the other hand, rather unexpectedly 'hiss' (Ezk.27:36), presumably because the dominance of international trade by this one power has excluded them from the share of the market to which they felt they had a right. John allows 
no such division of opinion over the fall of his Babylon-Rome. Without her there would be no commercial endeavour at all; therefore the merchants as well as the seafarers weep at her destruction. Her end means the end of all cultural endeavour: harpists, minstrels, flute-players and trumpeters fall silent. It means the cessation of crafts, and of basic cultural activities such as the grinding of the millstone and the lighting of the lamp. It means (echoing Jeremiah's word of judgment on Jerusalem) the silencing of the voice of the bridegroom and the voice of the bride (18:22-23). But to the list of those who lament the loss of human social culture John adds the 'kings of the earth', the very figures whose independence has been drained away by the fornication which they have committed with this monopolistic cultural force. And this is a point on which we must linger; for the relation between the empire and its client kingdoms is central to the prophet's view of how empire comes to destroy itself.

The beast from the abyss, you will recall, boasts of seven heads and ten horns - a detail which poses an insoluble problem of distribution to the artists of each generation who attempt to depict the mulier sedens - and they are explained in chapter 17 as follows. The seven heads represent both the seven hills of Rome and an unfinished series of emperors, of which (John tells us unambiguously) the sixth is now reigning. Beyond this series of seven emperors, the beast is to have a final manifestation as an 'eighth'. The ten horns are ten kings - not, as in the model in Daniel, a series of ten, for they all act together in concert. They must, then, represent the kings of the earth who have committed fornication with the harlot and over whom she exercises dominion. They are the constituent powers on which her extensive empire of trade and conquest is founded. These ten kings, John predicts, are to receive authority for one hour together with the beast $(7: 12)$. We are presumably to assume that this one hour is the eschatological climax of the mystery of evil - we see this moment in closer perspective at 19:19 when the two Messiahs meet in battle - the same hour as that in which the beast takes form as the eighth emperor. At this point they will do two things: they will unite with the beast to make war against the Lamb (17:13), and they will turn against the whore and devour her flesh and burn her up with fire $(17: 16)$. And this will be according to the 
purposes of God, who has 'put it into their hearts to carry out his purpose by being of one mind and giving over their royal power to the beast, until the words of God shall be fulfilled' $(17: 17)$.

This is a confusing scenario. The ten kings receive their royal power at the end of history, renounce it to the beast in an act of unanimity, turn upon the empire which has nurtured them, lament the fall which they have themselves encompassed, and then turn blindly and self-destructively against the Lamb. What coherence can we detect in this sequence of acts?

First, we remember that John is offering an analysis of empire which understands it as 'fornication', that is to say, the surrendering of individual integrity in an undisciplined and destructive form of commerce. Empire is not simply an extensive form of unified rule, but one which drains the integrity from all other powers and leaves them improperly dependent and impotent. Thus the ten kings are at once the dependents of empire and the victims of its capacity to arrogate all authority to itself. Their relation to it is that mixture of resentment and need which is characteristic of dependents. Now, the climax of the career of empire, as John sees it, is its dissolution under the force of the resentment which it has engendered. It may appear to have conferred unity on the constituent parts of which it is composed, and so it has. But that unity achieves its paradoxical height in the 'one mind' which unites its dependents in rebellion against the source of their own strength. This final paroxysm of self-destruction is the most complete disclosure of the unity which has been engendered by these means.

But this general thesis about the end of empire is woven together, in John's prediction, with an eschatological view of the end of the Messianic pretender. For the beast itself is destined to turn against the empire it has promoted - which is to say that the mystery of evil, though it has taken provisional and penultimate form in an apparently unified, coherent political structure, can achieve its ultimate self-disclosure only as every positive element, borrowed from created goodness, is strained out. The goal of the selfrevelation of evil is the vanishing point of unity in pure negativity. The logic of the beast's end and the 
logic of the whore's end is the same: predatory power collapses in upon itself. And so it is that the two ends are coordinated. It is as the client kings discover and express their unity in turning against its source that they offer the purest worship to the beast; and it is at that point, with the collapse of empire in a furiously united tumult of self-destruction, that the beast can make his final throw of outright war against the Lamb, carrying the force of united negativity against the throne of God himself. But of course it is in vain; for the 'one mind' with which the resentful powers unite to serve the beast and destroy their mistress is also borrowed from the mind of God himself. Its unity is a borrowed unity; the purposefulness of its evil was always a sign of its predatory dependence upon the good which it suppressed. The diabolical project of claiming the throne of lordship was from the beginning a self-contradictory project. The collapse of empire, then, reveals the operation of divine providence; and the future collapse of this Messianic empire will be a revelation of the final rule of God's Messiah over history. The disclosure of the mystery of evil was always at the service of divine providence for the overcoming of evil.

Almost everything we have observed so far has been by way of criticism of political phenomena, suggesting that the stance of the believer must be essentially antipolitical. The paradigm of political activity has been imperial conquest; the permanent political institution, the city, has merely served to sustain and develop the exploitation of imperial dominion by commercial means. The exercise of human freedom in response to the Word of God has thrown the believer into irresoluble conflict with the organised community. And in these last days empire has taken on a new significance as the form in which the Antichrist lays claim to wrest mankind's ultimate allegiance from God. Not even in the church can we see a form of social life which qualifies this negative judgment. The faithful believer appears in history as an individual ('him who conquers') or as a pair ('the two witnesses') standing against organised society. The very word 'church' is used by John only to designate the local communities which he addresses in his introductory letters. There is no place for the 
church catholic on earth. Only when we have lifted our eyes to heaven have we been allowed to see, at the end of history, the reality of a worshipping community: the Jewish and gentile faithful in chapter 7 and the community of first fruits in chapter 14.

For all this there is a reason. The root of any true social order, in which human beings relate to God and to each other lovingly, is the revelation of the conspicuous justice of God. We cannot comprehend how we are to live together until we know that God has shown us his judgments. For the good of social order is founded upon a judgment (dikaiōma), a declarative act which establishes righteousness (dikaiosunē). In divine judgment the paradoxical conflict between the freedom of the Word of God and the necessity of immanent justice in history is resolved. God's word becomes 'judgment'; its freedom creates the order of a concrete society. And the the necessity of history becomes 'judgment' too; its tragedy is turned into the freedom of the saints' obedience. It is quite clear at what point in the Apocalypse we are permitted to see this coming together of necessity and freedom in divine judgment. It happens in the third cycle of seven, which is introduced by the words of those who have obeyed and conquered the beast, 'Thy judgments have been revealed!' (15:4), and is accompanied by a confession of God's justice from the afflicted innocent beneath the altar, 'Yea, Lord God the Almighty, true and just are thy judgments!' (16:7). And it happens at precisely this point because in the preceding section, chapters 12-14, we have seen the Christ revealed and exalted and have heard the angels proclaiming the eternal Gospel, concluding with the vision of the Son of Man coming upon the cloud to judge. We may, then, expect that in the concluding sections of the Apocalypse we shall be shown the outline of a new social existence which is founded upon the judgments of God. This, of course, cannot be a product of history, because it is brought about by the judgment of God upon history. It is given from heaven, descending like a bride prepared for the bridegroom.

We have observed already that the vision of divine conquest, the central section of the three concluding sections (19:11 - 20:15), presents the victory over evil twice over in two pictures, first as a battle, then as an act of jurisdiction. The Messiah rides out to conquer the beast, and then there is a scene of judgment. Gog and Magog are gathered for battle, and then there is 
the judgment of the white throne. In the case of the first victory, the victory of the Messiah, the faithful share his judgment, seated on thrones with him, and reign with him for a thousand years $(20: 4)$. Those terms 'judgment' (krima this time, not dikaioma, which is reserved for the aboriginal constitutive act of God) and 'reign' invite us to consider the promise of an eschatological just order, a sharing in the authority and sovereignty which is given to all members of a true and well-founded community. Such a promise can be realised only by the victory of the true Messiah over the false. The word of truth has first to take form as a sword, issuing from the Messiah's mouth, to defeat those who live by the sword, in order for it then to take form as a judgment, to ennoble and give dignity to those whose social hope has been founded upon it alone. There is, of course, as has been often observed, something highly paradoxical about the picture of the Prince of Martyrs constituting himself the head of an army of conquest. It is an image which negates itself, cancelling, rather than confirming, the significance of the political categories on which it draws. It is what Aquinas called the merely 'symbolic predication of proportional analogy'. What is less often observed is that the analogy of judgment is not merely symbolic, and that here the political imagery does not negate itself. The idea of an ordered social existence under the authority of divine dikaioma, participating in that authority by the activity of human krima, is not a purely formal one. It conveys to us a hope that in the life which we are summoned to live with Christ we may experience, as a social reality, that authority of truth and righteousness which our experience of political society on earth has consistently denied us.

We must not fail to observe the implications of this. If it is right to say that the basis for a new order of society is God's word of judgment pronounced in Christ, then it follows that the witnesses who proclaimed that word to challenge the prevailing political order, were not acting anti-politically at all, but were confronting a false political order with the foundation of a true one. We must claim John for the point of view which sees criticism, when founded in truth, as genuine political engagement.

A right ordering of society is realised when mankind in Christ participates in the exercise of the Messiah's authority. But the judgment of the saints cannot be the 
last word about true judgment. When John turns from the triumph of the Messiah to the triumph of the Father, we are shown another act of jurisdiction, which belongs exclusively to God. To be part of an ordered community is to share in the exercise of its proper authority, yes; but more profoundly it is to be subject to the divine authority. For God's authority is not in competition with man's. From God's true speech flows all man's possibility of true speech; from God's judgment flows all man's possibility of judging. Not until we have stood before the great white throne and found ourselves judged there, can we possibly see, enter, or exercise our role in the Holy City, the new Jerusalem. (This is an example of how John's ordering of events is analytical rather than sequential: he proceeds from the judgment of the saints to the judgment of the Father as from an effect to its cause.) We would be well advised, we who love that ecstatic chapter with which John's Apocalypse closes, to remember how carefully and by what steps he has led us up to it.

Part of the impact of this astonishing chapter arises from the fact that we have come all this way, observing nations, races, armies, empires, kings, princes and merchants, simply to see a city - which we might have thought of as the primal form of human society. We have, of course, seen one city before this. Babylon-Rome was the Great City - the epithet distinguishing her from the New Jerusalem, who is the Holy City. John underlines the parallel between the two cities by repeating 17:1 almost verbatim at 21:9. In the tension between these two political symbols the whole conflict between good and evil is worked out: the city is the bride, and the city is the whore. But behind this opposition we will recall that there was a hint of their fundamental identity. In chapter 11 John was commanded to measure the temple but leave the outer court unmeasured, since it was given over to the gentiles who 'will trample over the holy city [note the epithet] for forty-two months' (11:2). In this same city, apparently, God appointed his two witnesses to prophesy and be slain, and their bodies to lie 'in the street of the great city [note the epithet] which is allegorically called Sodom and Egypt, where their Lord was crucified' $(11: 8)$. Here, then, the two epithets are assigned to the one city, which is given on this occasion neither the 
name Babylon nor the name Jerusalem, though it is associated with the historical Jerusalem by the reference to Jesus' death and by the presence of the temple. What are we to conclude from this? That the city is aboriginally the 'holy city', but has lost its name and its sanctity (apart from the temple in its midst) and is corrupted into a denial of itself? Here is the clearest statement of the aboriginal unity of the human community to set against the recurrent emphasis on its division. What we see as the two cities is in fact the corruption, and the hope of redemption, of the aboriginal one city.

The details of John's heavenly Jerusalem are drawn primarily from the vision of temple and city which occupies the concluding nine chapters of Ezekiel; but there are significant revisions. Ezekiel's holy city is built around a temple, and is set in the midst of a reorganised Holy Irand. John's is a city without a temple, and is set in the midst of a redeemed earth. In a highly significant qualification of Ezekiel 47:12 John says that the leaves of the trees which grow beside the river are for the healing of the nations. Thus John points to a universal restoration of the human community as Ezekiel never did. In the light of this we may wonder why, in equipping his guide with a measuring-rod, John did not follow through the implication of Zechariah 2:1-5 (to which he alluded in chapter 11) and declare that the eschatological city should be without walls, since it is protected by God's immediate presence (a logic he will not hesitate to follow when it suggests the abolition of the temple). The answer is, apparently, that he saw the city's walls not simply as a protection, but as a definition. The gates and walls are there not to exclude but to give form: their twelvefold structure confirms the city's continuity both with Israel (of the twelve tribes) and with the church (of the twelve apostles); but the ever-open gates show the elect community in its appointed openness to the world, providing the light by which the nations walk and the shrine to which the kings of the earth bring their glory $(21: 24)$.

To the reader who is not attuned to John's dialectical use of images this is an astonishing moment. He is unprepared to entertain the thought of a humanity living and thriving outside of the redeemed Jerusalem. 
Yet it is highly characteristic of our author to balance complementary aspects of his understanding in this way. As the city of the faithful, the community of the redeemed, the heavenly Jerusalem contains universality in itself. It is restored humanity, and 'outside' it there is nothing but rejection $(22: 15)$. Yet it is also the elect people, whose destiny it is to shed God's light into the whole world. This aspect, too, must be present in the imagery of the final state, especially as it balances and corrects the resentful and destructive relation of the client kings to the imperial city. In this vision of human completeness there must be a symbol of the mutuality which was destroyed by empire, which is yet compatible, John believes, with the exclusion of all that is in the service of evil. To ask him to do more than set these two images, the one of universal homogeneity the other of mutuality, alongside one another, is to ask him to be more theoretical than his vision allows him to be - or else to resolve the dialectic of election and universality improperly, by denying one side or the other.

At the heart of the city is the throne of God, which is now also, and eternally, the throne of the Lamb. John's city, like Ezekiel's, is the place where the Lord dwells. But whereas Ezekiel expresses this by making the temple dominate the city, John disposes of the cultic image apophatically: 'I saw no temple' (21:22). He shows himself in this way to be a Hellenistic Christian eschatological thinker, following the lead of the author to the Hebrews, for whom the cultic is the shadow of good things to come, dispelled by the actual form of them in Christ. The presence of God in community is unmediated; it is sheer presence. Therefore the temple 'is' the Lord God Almighty and the Lamb. The temple has been absorbed, we may say, into the throne. But to this observation we must add another: that the throne has become a place of divine speech. At 16:17 we heard God speak 'out of the temple, from the throne, saying, "It is done!"'; but now the voice which was heard through the mediation of the temple speaks immediately, no longer in secret communion with men, but in open settlement of the affairs of the universe. Its words form the goal of the whole Apocalypse, giving a decisive interpretation to the final vision, which is itself the interpretation of all the other visions. 
These final words of God are found at 21:3-8. They consist of a declaration of reconciliation, 'Behold, the dwelling of God is with men...', and a declaration of judgment, 'To the thirsty I will give from the fountain of the water of life...but as for the cowardly etc.'. And these two declarations flank three short utterances about the beginning and end of all things: 'Behold, I make all things new.' 'Write this, for these words are trustworthy and true.' 'It is done! I am the Alpha and the Omega, the beginning and the end.' With these three words we stand in the sanctum sanctorum of history. Everything is stripped away; even judgment and reconciliation stand to one side. We confront the sheer act and being of God. He who by his mere decision created the heaven and the earth, now by his mere decision makes all things new, conferring upon creation a 'history' and a fulfilment. The words 'I make' and 'All is accomplished' complement one another: there is no futurity about the first, no preterity about the second. History is summoned into being by God's everpresent declarative act, and there and then it is accomplished, reflecting back the glory of the one who summoned it, who can now be known as Alpha and Omega, its source and end.

But in between 'I make' and 'All is accomplished', at the centre of the three utterances, which are the centre of God's final speech, which is from the throne at the centre of the heavenly city, there stands the command to the prophet 'Write!'. An astonishing thing, that the prophet should find his own task at the very heart of the ineffable being and act of God! But in the sovereign decision of God to constitute history, there is implied a decision that history should make him known. He who can declare himself Alpha and Omega, does declare himself so in order to make that declaration heard. At the heart of God's self-announcement is the announcement that he is the self-announcing God, not merely self-subsisting but self-communicating. 'In the beginning was the Word; and the Word was with God, and the word was God.' On that self-communication, mediated to us by prophetic speech, the holy city is founded. At the heart of politics is true speech, divine speech, entering into conflict with the false orders of history, the guarantor of the only true order that the universe can ever attain. 